\title{
Strategy Research on the Interactive Teaching Model
}

\author{
Bin Wang \\ Foreign Languages Department \\ Liaoning Institute of Science \&Technology \\ Benxi, China 117004
}

\begin{abstract}
In the process of acknowledging education is the interaction of teaching and learning, the modern educational idea fully affirms interactive teaching model is a model of innovative classroom teaching. This paper elaborates the change of traditional teaching concept and the benign improvement of teaching through the interactive teaching model between teachers and students from several aspects.
\end{abstract}

Keywords-interactive teaching; modern education theory; regulation

\section{INTRODUCTION}

Modern education theory thinks teaching is an interaction of teaching and learning between teachers and students, in order to achieve the aim of improving the overall quality of students and developing creative potential of them. In the contradiction of teaching and learning, both sides are positive factors. The so-called "interactive" teaching model means fully stimulating positive factors of the two and letting the whole teaching process in resonance, interaction and cooperation. Grasping "interactive" teaching principles is an important premise to orderly and efficiently implement "interactive" teaching model. The "interactive" teaching principles include active principle, initiative principle, dynamic principle and democratic principle.

The interactive teaching not only makes the atmosphere active and improves teaching quality but also furthest arouses the enthusiasm of students in learning.

Interactive teaching model is a model of innovative classroom teaching. It emphasizes the mutual exchange, mutual communication and mutual cooperation between teachers and students and between students. The dynamic process with the interaction of teaching and learning coordinates the relationship between elements in teaching and between human and teaching environment to produce teaching resonance and promote the participation of students and realize mutual promotion, in order to achieve the purpose of stimulating innovation potential. Innovation is also the ultimate goal of the interactive teaching, and the realization of

Project: Based on Stratification +Diversified Practice, Applied Foreign Language Teaching Model Research \& Practice

Project No.: JG16DB232 (Liaoning Province Education \&Science Planning Projects in 13th Five-Year, 2016)

Project: Position Ability Oriented, Characteristic of Additional Practice Term, Construction of the Training System of English Professional Talents

Project No.: 1st Batch of the Projects of The Reform and Development of Education and Teaching in Liaoning Institute of Science \&Technology it includes the following aspects.

\section{To Give Full Play to the LEAding Role OF TEACHERS}

Teachers shall play the role of organizers and instructors in the teaching process and mainly coordinate and guide in the implementation of the "interactive" teaching model. The teaching of teachers shall be subject to the learning of students. Teaching aims at learning and leads learning. Teachers should guide and promote learning through teaching. Only the full embodiment of teachers' dynamic role can guarantee the orderly and compact progress of "interactive" teaching.

Serving and promoting the learning of students, the teaching of teachers mainly has two functions, namely orientation function and regulatory function.

The orientation function of teachers is shown as follows The first is "introduction". Teachers guide students to perceive and understand the textbook through meticulous design and point out the important knowledge and the professional contents of knowledge that students have to grasp. For example, when teaching Jane Austin, teachers shall let students grasp her basic information (including birth, death and homeland), literary position, writing career, master works, writing style and representative works and guide how to appreciate. The second is "guidance on thinking". The innovation potential of students can be trained through the creation of problem situation. The design of problems must base on the textbook and embody the comprehensive application of knowledge, expand thinking space to cultivate the creative spirit of problem solving. For example, when teaching the writing style of Austin through analyzing the works, teachers can guide students to appreciate and think with problems and find out the answers according to the literary form of creation, theme and language function. The third is "guidance on learning", which means training the ability of students in learning literature through giving guidance on learning methods. Teachers should let students grasp the methods of reading textbook, comparing the difference and resemblance, evaluating works and appreciation.

The regulatory function of teachers includes organizational regulation, time and space regulation and emotional regulation. The teaching process is overall. The "interactive" teaching is open but not "slack". The classroom teaching will be inattentive if enough freedom is given to students. Therefore, it requires teachers to regulate orderly on the basis of full preparation and meticulous design. The execution of teaching 
scheme, teaching-learning feedback and communication and the treatment of emergency situation must be included in the regulation. Teachers must predict the time arrangement and control of teaching links and adjust according to the physical truth, give time and space for students to participate activities at the same time reasonably arrange and control. Furthermore, the emotional infection of teachers is of vital importance. Only spirited and passionate teachers who can adapt themselves to changing circumstances can arouse the enthusiasm of students in learning, adjust their learning emotions and strengthen their rational feeling.

\section{To Highlight THE INITIATIVE OF STUDENTS IN ACTIVE PARTICIPATION IN LEARNING}

Students are the subject of learning and in the central position of the "interactive" teaching process. Implementing the principle of the learning initiative of students must depend on the links of "I want to learn", "I can learn" and "I can learn well".

First, teachers should stimulate the self-awareness of students in learning. Only the clear learning objectives can turn into the behavior of conscious learning. From the perspective of ultimate goal, the era of knowledge economy needs intellectual talents. Students will pay a heavy price if they do not develop personality and improve ability through learning. From the perspective of disciplinary objectives, teachers should make students realize learning literature is not only to deal with the final examination. With the unique disciplinary advantage, literature can enrich people's knowledge, cultivate morality, perfect personality and develop strong points. Students will benefit enormously if they learn literature well and develop overall quality.

Second, students should be trained the habit of active participation in learning. Firstly, they should develop the habit of preparing lessons before class. Preview is not fangle but the prelude of active learning in class. The perception of textbook and preliminary acquaintance of learning contents can extend to the level of deep understanding. Secondly, students must become the master of learning and conduct the active engagement and participation in learning. Thirdly, students must learn to communicate with others, question and argue repeatedly, express opinions and bring out the best in each other, in order to make teaching benefit teachers as well as students.

For example, before appreciating the Sleepy Hollow, the masterwork of Washington Irving, the author assigns five thinking questions to students first, and then lets students read the original text, and questions according to the text when giving a class in the next day. Because having previewed the contents, many students can answer these questions and are willing to participate and become active in group discussion or collective debate.

For the contents of each class, teachers can guide students to preview through asking questions in advance, so that students will gradually develop the good habit of previewing and play the prelude of each class well. Besides, the self-study and research ability of students must be improved. In essence, the degree and quality of the active participation of students in teaching depend on their self-study and research ability. The guiding role of teachers is the catalyst, and the self-study and research ability of students are internal impetus. When possessing abilities of self-study, obtaining activity information and using knowledge to solve problems, students will have new understanding and experience in knowledge on the textbook and further explore new problems. Here, I only introduce one method, assigning tasks for students to learn to write book report and literary review in different views. The wide reading and the preview of teaching contents and information retrieval train self-study ability of students and enable them to learn methods of how to learn.

\section{To Embody the FleXIBLE DyNAMIC PRINCIPLE}

Different types of teaching materials, different learning demands of students and alternatives of teaching methods and means, especially the constant communication and feedback of teaching and learning in the teaching process make the "interactive" teaching model dynamic. The dynamic teaching becomes the prominent feature of the "interactive" teaching.

Firstly, the static knowledge on textbook must be turned into dynamic information. The textbook of literature is static, which requires us to rearrange and redesign according to the cognitive structure and teaching requirements and transform it into more visual information by virtue of multimedia tools. For example, "Pride and Prejudice", the masterwork of Jane Austin, is the static text, but the teaching contents will be vivid and appealing if it is made into a movie. Turning the contents on textbook into questions to let the cognition and understanding of students become active is also a method of changing static knowledge into dynamic knowledge. For example, what's the theme reflected in the "Pride and Prejudice"? In this way, teachers can guide students to analyze, judge and appreciate a masterwork via rational thought.

Secondly, the passive listening should be turned into active learning. From the perspective of learning, except for obtaining information, students must internalize it into selfachievement. Therefore, the learning process is the activity that involves visual sense and auditory sense. Students must use mouth, hands and brain and fully stimulate functions of organs in learning. Teachers must abandon the "duck-stuffing" type of teaching that teachers speak and students listen. The interactive teaching must be adopted to strengthen the two-way communication of teachers and students and improve the ability of students in active thinking. Besides, teachers should encourage students to think, speak, do and innovate. To arouse the enthusiasm students in thinking problems, teachers don't criticize opposite opinions even wrong views of students but guide actively. For example, when discussing the Scarlet Letter of N Hawthorne, a student sympathized with the bishop Dimsdale, who is a negative character in the novel. I didn't deny but smiled and asked why. As a result, she said Dimsdale is devoted to his duty and loyal to love and the reason why he refuses to acknowledge Hester Prynne and daughter Pearl is professional needs. The sympathetic student who dares to innovate and think is precious. It's necessary for teachers to correctly support and encourage them. 
Thirdly, the single teaching method must be turned into diversified one. According to different teaching materials, teachers should adopt different teaching methods to better meet the needs of dynamic teaching and truly change the oneway teaching to feedback communication. For example, students can commonly discuss some works, but in the Fall of the House of Usher, the obscure work of Edgar Alan Poe, it's difficult for students to think of the symbolic implication of the "House" in the story: the elapse of rational time. Therefore, only the teaching method of "analysis - conclusion-forward looking_positioning" can be adopted.

\section{The DEMOCRATIC PRINCIPLE THAT ESTABLISHES THE RELAXED AND HARMONIOUS ATMOSPHERE}

The space of classroom teaching is not a vacuum place but full of invisible but the most sensitive human factors: the harmonious interpersonal relationship, active classroom atmosphere, enthusiastic learning emotion and competitive learning system, which have become important parts in modern education theory. The important links that cannot be neglected in the process of "interactive" education include forming the equal and democratic teaching atmosphere, building challengeable and competitive teaching system and establishing the normal and close cooperation relationship.

The education must be people-oriented. The humanism of education aims at the harmonious development of people and the maximum realization and development of human nature, dignity and potential in the educational process. The humanism of education often criticizes the mainstream education. It opposes the dominance of education through presupposed, humanistic and external educational purpose, and aims at the self-development of students, emphasizes the development of human nature, personality and potential.

It's necessary to establish the harmonious relationship between teachers and students that students respect teachers and teachers care for students and they can understand each other and communicate. Teachers must care for students and become tolerant, abandon the absolute authority and become scholarly mentor and beneficial friend of students. On the basis of equality, mutual respect and understanding, students dare to and take delight in participating in teaching, so that the teaching and learning will integrate and promote each other.

Students should form a good learning psychology. The questionnaire after the educational reform in 2003 shows almost 60 percent of students like literature, 40 percent take a neutral attitude, and the proportion of students who dislike it is zero. Although the result is good, it includes the emotion of worrying about examination, factors of teaching methods and examination stress and psychological obstacle of students in learning. It seems very important to emphasize psychological counseling, guide students to overcome the psychological obstacle in learning and form a good learning mood and strengthen self-confidence. "Innovation is the spirit of a nation." The statistical result of this educational reform indicates only the breakthrough and innovation of teaching methods can arouse the enthusiasm of students in learning, develop their ability of creative thinking and strengthen learning confidence. The "interactive" teaching just reflects the innovative meaning, but it's a pity that few students fail to know what the "interactive" teaching is.

\section{CONCLUSION}

The information technology brings new changes for the traditional teaching model, teaching methods and teaching means. The educational method that "a chalk and a blackboard dominate the class" has failed to meet the requirements of modern education. During the process of promoting course teaching reform and training the innovation consciousness and practice ability of students, teachers should play a more important role in elaborately designing the teaching process according to the development of students, which is the teaching method of teaching a man to fish. Just as professor Ye Lan of East China Normal University says, "return classroom to students and let it full of vitality; return class to students and let it full of growth atmosphere; return creativity to teachers and let the teaching full of wisdom and challenges; return the initiative in the development of spiritual life to teachers and students and let schools full of vigor".

\section{REFERENCES}

[1] Ellis, R. Second Language Acquisition Research [M], Shanghai: Shanghai Foreign Languages Education Press, 1997, page47-64

[2] Harmer, J. How to Teach English[M]. Peking: Foreign Language Teaching \& Research Press, 2000,08.

[3] Littlewood, William. Foreign and Second Language Learning[M]. Cambridge University Press, 1984

[4] McCarthy, M. Discourse Analysis for Language Teachers[M]. Cambridge: Cambridge University Press, 1991, page47-56.

[5] Willis J. \& Willis, D. Challenge and Change in Language Teaching[M] Shanghai: Shanghai Foreign Language Education Press, 2002, page126134.

[6] Wu Weiren: A Brief History of British and American Literature and Selected Readings [M] 1988, Foreign Language Teaching and Research Press, 2002

[7] Jeremy Flarmer, How to Teach English, [M] First Edition in August 2000, Foreign Language Teaching and Research Press, 2003, 1 